\title{
CHANGES OF THE PHYSICAL-WATERS PROPERTIES OF MURSHIC ENDOFIBRIC HISTOSOLS IN THE ASPECT OF LONG-TERM INVESTIGATION ON THE DRAINAGE OBJECT SUPRAŚL DOLNA
}

\author{
Aleksander Kiryluk ${ }^{1}$ \\ 1 Faculty of Civil and Environmental Technology, Bialystok University of Technology, Wiejska, 45E Str., \\ 15-351 Bialystok, Poland, e-mail: kiryluk@pb.edu.pl
}

Received: 2017.05.29

Accepted: 2017.08.01

Published: 2017.09.01

\begin{abstract}
The paper deals with the study upon changes within the physical and water properties of murshic endofibric histosols in the drainage meadow object Supraśl Dolna. The scope of studies includes the description of the soil profiles, thickness of diagnostic layer, bulk density, full water capacity, porosity, ash content, and peat decomposition. The long-term investigation carried out in 1982-2015 allows for observing the changes within these soils. The changes were studied in two habitats: wet and dry. In wet habitat, the groundwater flowed 30-98 $\mathrm{cm}$ below land surface and supplied the rhizosphere zone. Dynamics of groundwater surface were dependent on the size of precipitation during vegetation period and peat decomposition degree within the soil profile. In the dry habitat, the level of groundwater decreased up to $110 \mathrm{~cm}$ (below peat layer). Adverse water conditions in the dry habitat (temporal and long-term water deficiency) caused the increase in bulk density to $0.405 \mathrm{~g} \cdot \mathrm{cm}^{-3}$; simultaneously, a decrease in full water capacity to $82.5 \%$, as well as faster peat mineralization occurred. In wet habitat, physical and water properties of murshic endofibric histosols were not significantly altered. In order to inhibit the peat decomposition rate and delay the peatland degradation, optimum moisture content should be maintained within the soil profile along with rational meadow management.
\end{abstract}

Keywords: peat, diagnostic layer, ground water level, moisture content, full water capacity, bulk density

\section{INTRODUCTION}

In Poland, there are about 55 thousand peatlands (of area $>1$ ha) covering about 12.5 thousand $\mathrm{km}^{2}$ total area. In terms of the number and area, fen peatlands localized in river valleys, prevail. The largest fen peatlands occur in valleys of the following rivers: Biebrza, Narew, Noteć, Łeba, lower Oder and outskirts of Zalew Szczeciński [Ilnicki and Szajdak 2016]. Fen peatlands play important economic, natural, and environmental roles (high-productive post-bog meadows) [Kiryluk 2007]. Fen peatlands in their wet state, due to high porosity of peat (even up to $85 \%$ vol.), also have a great ability to retain water. This feature can be decreased even by $20 \%$ due to excessive peat dehydration during drainage works. Intensive dehydration and agricultural management of peatlands began in $18^{\text {th }}$ century in Poland and the largest areas of peatlands were drained at the end of $20^{\text {th }}$ century. Due to drainage works, the water resources in Polish peatlands could decrease by about 160 million $\mathrm{m}^{3}$ [Ilnicki 2002].

Every drainage of fen peatland inhibits the peat accumulation and contributes to its faster mineralization [Pawluczuk and Gotkiewicz 2003; Renger et al. 2002]. Apart from peatland drainage, the depth of groundwater level and its dynamics are the most important factors affecting the range and changes rate in physical and water properties [Cieśliński 1997]. It is important during the soil formation process, and also determines the rate of 
degradation processes (loss of organic matter) occurring due to habitat and anthropogenic factors.

There are a few reports in Polish literature upon changes in post-bog habitats within longer time-frame after drainage works and in changing climatic conditions.

The aim of the study was to investigate the scope and rate of physical and water properties in drained meadow object under the conditions of decreasing precipitation during vegetation periods. It should be helpful in estimating the most appropriate economic use of fen peatlands, and in determining the manner of their protection in terms of water resources maintenance in the majority of the catchment area [Joosten 2000]. The studies on changes in murshic endofibric histosols properties conducted over longer periods of time (33 years) can be important due to a longer time interval after peatland drainage and longer period of observations. The investigations carried out under conditions of varied meadow utilization of Supraśl Dolna object and its localization near Białystok city agglomeration, should indicate the most appropriate way to protect that valuable peatland ecosystem against further degradation.

\section{STUDY AREA AND METHODOLOGY}

The object Supraśl Dolna covers the area of about 1550 ha. It is situated in a valley fragment of river at $0+000$ to $29+400$ kilometer of its course (Figure 1). Drainage works carried out in 1975-1977 reconstructed the existing main ditches and a network of new ditches with drainage and irrigation functions were created. At present, there are about $90 \mathrm{~km}$ of drainage-irrigation ditches, 57 water damming locks, 127 throttle-locks, and about 500 drainage throttles, within the studied object. The object is characterized by diverse meadow utilization. Extensively used meadows prevail, while strict meadow management is performed over only $20 \%$ of the area. Majority of the area is covered by one-cut meadows. Some of the problems include the excessive nitrogen release from peat mineralization, strong water eutrophication, and enlargement of nitrogenous phytocenoses area (Urtica dioica) [Kiryluk 2007]. The use of nitrogenous fertilizers only is a fallacy in meadow management, which results in release of $150 \mathrm{~kg} \mathrm{~N} \cdot \mathrm{ha}^{-1}$ in dehydrated peat due to mineralization.

The study was carried out in a drained object Supraśl Dolna (km 7+500 to $15+300)$ in two habitats: wet (profile 1) and dry (profile 2) (Figure 1).
The studies included a detailed description of the profiles and testing the physical and water properties of murshic endofibric histosols. Soil samples were collected in 1982, 2002, and 2015 in constant sites of soil profiles localization at the beginning of the study. In wet and dry habitats, 4 soil outcrops were made to describe the soil morphology according to obligatory systematics [IUSS 2014]. Soil classification and nomenclature of horizons was applied according to PTG's soil systematics (2011) adjusted to the international soil classification system [IUSS 2014]. The assessment of peat decomposition degree was performed using von Post scale. Soil samples from outcrops at 5-10 25-30, 55-60, and 95-100 cm (profile 1) and 5-10, 25-30, 55-60, and 75-80 (profile 2) were collected into metal cylinders with the capacity of $100 \mathrm{~cm}^{3}$ and subsequently used to conduct physical and water tests. The samples were taken in 4 replicates [OKRUSZKo, 1977]. Bulk density was determined in the samples collected into cylinders without damaging their natural structure. The samples were dried to a constant weight at $105^{\circ} \mathrm{C}$. The ash content was determined by means of annealing at $550{ }^{\circ} \mathrm{C}$ [Sapek \& Sapek, 1997]. Full water capacity was determined by gradual full saturation (to constant weight) of samples completely flooded with water. The groundwater level in the considered wells was measured every month.

\section{RESULTS AND DISCUSSION}

\section{Study of morphology and description of soil profiles}

Murshic endofibric histosols were developed from fibric peat, grainy moorsh, reed swamp, and organic limnic soils due to dehydration of deposits. A distinct diagnostic level of muck was formed in the process of aerobic transformation of organic material [Systematyka 2011].

\section{Systematics and description of soil profile No 1}

Profile No. 1 was located in an off-road, in the bend of the Supraśl river. A periodical fluviogenic process occurs at this depression (during early spring floods and at higher flows in the Supraśl river). This process improves the humidity of the soil profile and slows down the mucking process. Meadows are used extensively (single mowing). 
Soil systematics: Order 10. Organic soils (O) Histosols, Type 10.6. Murshic histosols (OM), Sub-type 10.6.1. Murshic Endofibric Histosol (OMi). Depth of tested soil profile to ground level (fluvic) C $131 \mathrm{~cm}$ - deep soil.

Soils in profile No. 1 (Table 1) were formed from reed swamp, mainly under the influence of fluviogenic processes. The M1 level of $17 \mathrm{~cm}$ thickness, in which grainy moorsh is present, is distinguished in this profile. Below, there is a peat level Oe of $12 \mathrm{~cm}$ thickness, comprising a small amount of decomposed reed swamp. At a depth of $31-131 \mathrm{~cm}$, there is the peat level Oi, also formed of a small amount decomposed reed swamp. Peat formations are deposited on a sandy substrate. In that profile, in comparison to profile No. 2, changes in physical and water properties occurred slightly.

\section{Systematics and description of soil profile No 2}

Profile No. 2 was localized in the upper part of the object subjected to the intensive dehydration using drainage ditches and through the adjacent Biała river (left tributary of Supraśl river). Lower thickness of the profile and temporal loss of water affect the larger changes in murshic endofibric histosols properties.

Soil systematics: Order 10. Organic soils (O) Histosols, Type 10.6. Murshichistosols(OM), Subtype 10.6.1. Murshic endofibric histosol (OMi).

Depth of tested soil profile to ground level (fluvic) C $85 \mathrm{~cm}$ - moderately deep soil.

Soils in profile No. 2 (Table 2) also developed from the reed swamp. The profile was classified to moderately deep organic soils. There is the moorsh horizon M1 of $18 \mathrm{~cm}$ thickness containing humic moorsh. Below, there is peat horizon Oil with the thickness of $19 \mathrm{~cm}$, where moderate- ly decomposed reed swamp is found. At the depth of $38-85 \mathrm{~cm}$, there is the peat horizon Oi2 built of weakly decomposed reed swamp. Sand is present in that profile at the depth below $85 \mathrm{~cm}$. As compared to profile No. 1 (deep soil), profile No. 2 contains horizon Oil composed of moderately decomposed peat. Larger changes in physical and water properties occurred in this profile.

The groundwater level in the drained peatland was subject to considerable oscillations during the year. The amplitude of groundwater level in the drained peatlands can range from 0 to $180 \mathrm{~cm}$ [Ilnicki and Szajdak 2016]. The level of groundwater in the studied peatland was shaped mainly by the amount of supplied precipitation and also by the water discharge through drainage ditches (Figure 1).

The largest drop in the groundwater level was recorded in June-September in the profile with dry habitat. In the years with very low precipitation sum, the groundwater level decreased up to $110 \mathrm{~cm}$ below terrain. In the wet habitat of deep murshic histosol profile (profile No. 1), groundwater flowed $30-98 \mathrm{~cm}$ below the land surface. Less altered physical properties of soil in this habitat and groundwater level similar to the optimum one, made favorable conditions for the growth and development of phytocenoses occurring under such circumstances [Podlaska 2000, Tomaszewska and Kołodziejczyk 2010]. The most important factor affecting the groundwater level in the drained object was the precipitation sum during the study and functionality of drainage-irrigation devices [Kiryluk 2007].

The physical and water properties of murshic endofibric histosols after draining are to the highest extent changed by groundwater. In profile No. 1 (Table 3), under the conditions of optimum moisture content, high porosity maintained in every diagnostic level, while bulk density was not changed above $0.281 \mathrm{~g} \cdot \mathrm{cm}^{-3}$. The positive

Table 1. Description of the profile of deep murshic histosol

\begin{tabular}{|c|c|l|}
\hline Diagnostic layer & Thickness of diagnostic layer $(\mathrm{cm})$ & \multicolumn{1}{|c|}{ Description } \\
\hline M1 & $0-17$ & grainy moorsh \\
\hline Oe $(\mathrm{T} 1)$ & $18-30$ & reed swamp, gray, weakly decomposed \\
\hline Oi (T2) & $31-131$ & reed swamp, brown, very weakly decomposed \\
\hline C & $>131$ & sand \\
\hline
\end{tabular}

Table 2. Description of the profile of moderately deep murshic histosol

\begin{tabular}{|c|c|l|}
\hline Diagnostic layer & Thickness of diagnostic layer $(\mathrm{cm})$ & \multicolumn{1}{c|}{ Description } \\
\hline M1 & $0-18$ & humic moorsh \\
\hline Oi1 (T1) & $18-37$ & reed swamp, gray, moderately decomposed \\
\hline Oi2 (T2) & $38-85$ & reed swamp, brown, very weakly decomposed \\
\hline C & $>85$ & sand \\
\hline
\end{tabular}




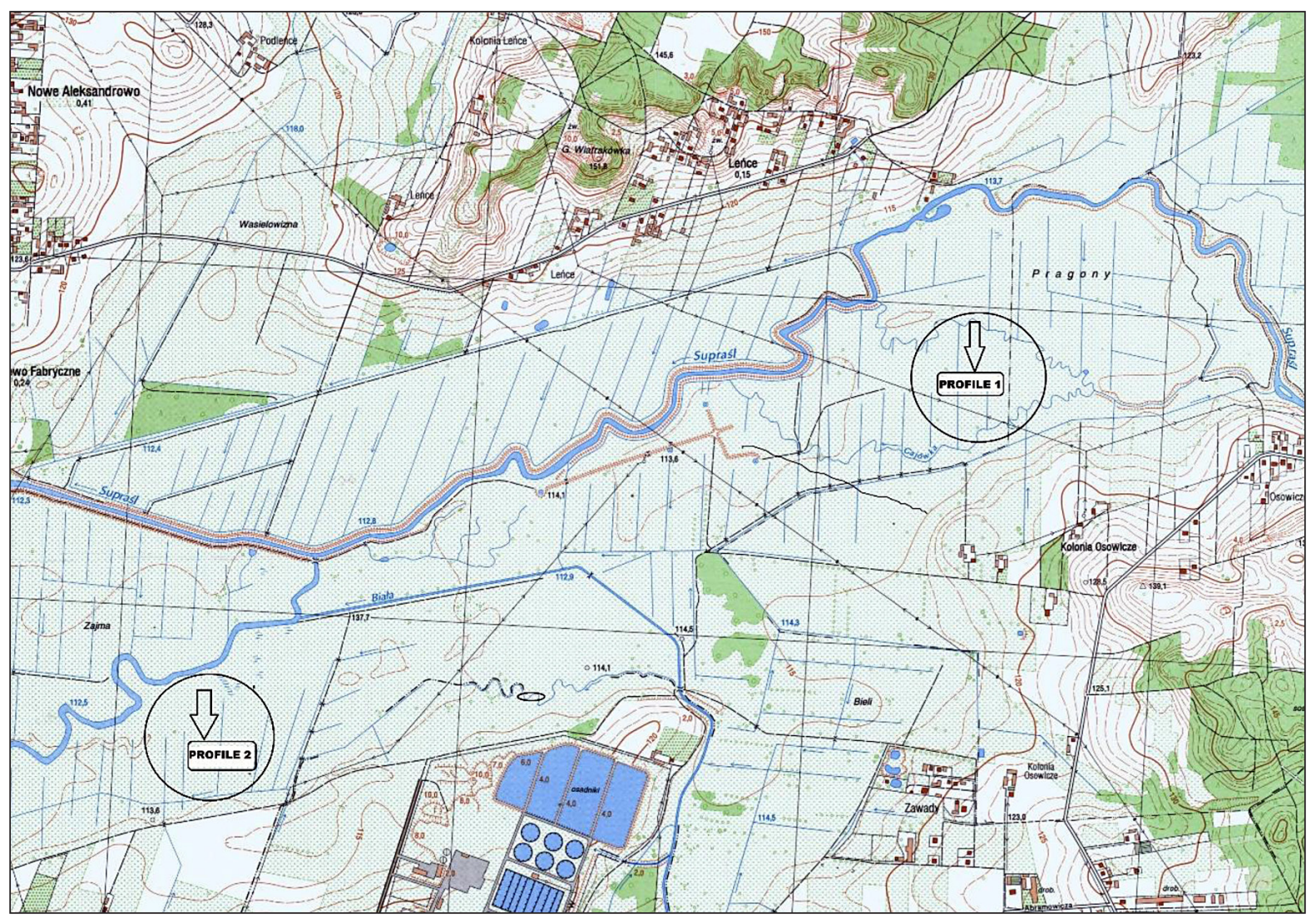

Figure 1. The fragment of valley Supraśl river in km: 7+ 500 do $15+300$. Own study on the basis of GUGiK topographic map Nowe Aleksandrowo N-34- 107-A-c-4

impact of groundwater on physical properties of peat soils is indicated by the studies carried out in Biebrza peatlands [Brandyk et al.2006; Renger 2002]. Murshic endofibric histosols in optimally wet habitat were characterized by a narrow range of changes in 1987-2007 (Table 3). The thickness of $M_{1}$ horizon increased by $3 \mathrm{~cm}$, while the thickness of Oe horizon decreased by $1 \mathrm{~cm}$. On the other hand, the thickness of Oi horizon did not alter. The bulk density of moorsh in the swamp horizon increased by $0.025 \mathrm{~g} \cdot \mathrm{cm}^{-3}$. The current humidity of moorsh horizon during the study decreased by $5.9 \%$ vol., whereas in the swamp horizon $\mathrm{T}_{1}$ it was changed only slightly. The changes in the full water capacity of tested soils were negligible. The values of physical and water properties in dry habitat (Table 4) were significantly different from the reference values for optimally wet peatlands after draining.

In dry object (profile No. 2, Table 4), the changes in physical and water properties were more clear and higher than in wet complex. The thickness of moorsh horizon $M_{1}$ increased by 7 $\mathrm{cm}$, while that of $\mathrm{Oi} 2$ decreased by $10 \mathrm{~cm}$. These changes indicate the intensity of processes occurring during the whole study period. The bulk density of moorsh increased in all diagnostic layer, with the most pronounced result in $\mathrm{M}_{1}$ (by 0.094 $\left.\mathrm{g} \cdot \mathrm{cm}^{-3}\right)$. Full water capacity in moorsh horizon decreased by $3.4 \%$ vol.

The retention capacity of peat moss soils is mainly due to the high peat porosity. In the study of the physical and water properties of the Mazurian Lake District peatlands, the retention capacity was estimated on the basis of the size of full water capacity [Pawluczuk, Gotkiewicz 2003]. The highest value of full water capacity occurred in the deep peat-fiber soil profile $\mathrm{Oi}_{2}$, which amounted to $89.4 \% \mathrm{vol}$. This parameter decreased slightly over a period of 33 years. The ash content of the studied murshic endofibric histosols should be regarded as average and its size is due to the small deposition of material from the fluviogenic process. In deep soil (profile No. 1), its value ranged from $12.3 \%$ to $16.8 \%$. Most of the mineral material was found in the moorsh level, which could have been due to the fluviogenic process as well as organic matter mineralization. In the profile of moderately deep murshic endofibric histosols, the range of ash content was $11.6-17.5 \%$. The degree of peat degradation in both examined profiles, according to von Post's scale, in the profile of deep peat soil ranged from $\mathrm{H} 3$ to $\mathrm{H} 7$. The highest degree of decomposition 
Table 3. The changes of physical and water properties of Murshic Endofibric Histosols in optimum moistening conditions in 1982-2015 years in soil profile 1

\begin{tabular}{|c|c|c|c|c|c|c|c|c|c|}
\hline \multirow{3}{*}{ Properties } & \multicolumn{9}{|c|}{ Diagnostic layers } \\
\hline & \multicolumn{3}{|c|}{$\begin{array}{l}\text { Murshic layer } \mathrm{M}_{1} \\
\text { well decomposed peat }\end{array}$} & \multicolumn{3}{|c|}{$\begin{array}{c}\text { Fibric layer Oe } \\
\text { moderately decomposed peat }\end{array}$} & \multicolumn{3}{|c|}{$\begin{array}{c}\text { Fibric layer Oi } \\
\text { very weakly decomposed pea }\end{array}$} \\
\hline & 1982 & 2002 & 2015 & 1982 & 2002 & 2015 & 1982 & 2002 & 2015 \\
\hline $\begin{array}{l}\text { Thickness of diagnostic } \\
\text { layer }(\mathrm{cm})\end{array}$ & 15 & 18 & 18 & 31 & 30 & 30 & 82 & 83 & 82 \\
\hline Bulk density $\left(\mathrm{g} \cdot \mathrm{cm}^{-3}\right)$ & 0.256 & 0.268 & 0.281 & 0.244 & 0.251 & 0.275 & 0.165 & 0.162 & 0.164 \\
\hline Full water capacity (\% vol.) & 83.7 & 82.5 & 83.5 & 88.6 & 87.5 & 87.1 & 89.4 & 88.7 & 89.0 \\
\hline Porosity & 85.1 & 85.6 & 84.3 & 89.2 & 88.8 & 88.6 & 91.4 & 91.0 & 91.3 \\
\hline Ash content (\% DM) & 16.3 & 16.6 & 16.8 & 14.5 & 14.7 & 14.6 & 12.3 & 12.5 & 12.4 \\
\hline Degree of decomposition* & $\mathrm{H} 7$ & $\mathrm{H} 7$ & $\mathrm{H} 8$ & $\mathrm{H} 4$ & $\mathrm{H} 4$ & $\mathrm{H} 4$ & $\mathrm{H} 3$ & $\mathrm{H} 3$ & $\mathrm{H} 3$ \\
\hline
\end{tabular}

* describing according to the von Post scale

Table 4. The changes of physical and water properties of Murshic Endofibric Histosols in periodically dry conditions in 1982-2015 years in soil profile 2

\begin{tabular}{|c|c|c|c|c|c|c|c|c|c|}
\hline \multirow{3}{*}{ Properties } & \multicolumn{9}{|c|}{ Diagnostic layers } \\
\hline & \multicolumn{3}{|c|}{$\begin{array}{l}\text { Murshic layer } \mathrm{M}_{1} \\
\text { well decomposed peat }\end{array}$} & \multicolumn{3}{|c|}{$\begin{array}{c}\text { Fibric layer Oi1 } \\
\text { moderately decomposed peat }\end{array}$} & \multicolumn{3}{|c|}{$\begin{array}{c}\text { Fibric layer Oi2 } \\
\text { very weakly decomposed peat }\end{array}$} \\
\hline & 1982 & 2002 & 2015 & 1982 & 2002 & 2015 & 1982 & 2002 & 2015 \\
\hline $\begin{array}{l}\text { Thickness of diagnostic } \\
\text { layer }(\mathrm{cm})\end{array}$ & 12 & 18 & 19 & 15 & 17 & 18 & 58 & 50 & 48 \\
\hline Bulk density. $\left(\mathrm{g} \cdot \mathrm{cm}^{-3}\right)$ & 0.311 & 0.398 & 0.405 & 0.276 & 0.283 & 0.290 & 0.165 & 0.174 & 0.178 \\
\hline Full water capacity (\% vol.) & 81.7 & 80.1 & 78.3 & 83.5 & 83.0 & 82.9 & 87.7 & 88.1 & 88.0 \\
\hline Porosity & 83.2 & 85.6 & 79.0 & 84.7 & 84.6 & 83.2 & 89.5 & 89.2 & 89.0 \\
\hline Ash content (\% DM) & 17.2 & 17.3 & 17.5 & 15.2 & 15.5 & 15.7 & 11.8 & 11.7 & 11.6 \\
\hline Degree of decomposition* & $\mathrm{H} 7$ & $\mathrm{H} 7$ & $\mathrm{H} 8$ & $\mathrm{H} 4$ & $\mathrm{H} 4$ & $\mathrm{H} 4$ & $\mathrm{H} 3$ & $\mathrm{H} 3$ & $\mathrm{H} 3$ \\
\hline
\end{tabular}

* description according to the von Post scale

was found in the moorsh level. It should be emphasized that many scientific and utilitarian works concerning the changes in the post-bog habitats within peatlands of the Biebrza river valley were carried out in the second half of the $20^{\text {th }}$ century by the Institute of Land Reclamation and Grassland Farming (now the Institute of Technology and Nature) in Falenty and by SGGW in Warsaw [Brandyk et al. 2007]. Synthesis of the research on changes in lowland bogs was developed by Ilnicki and Szajdak [2016]. At present, no proper water and meadow-pasture management is performed on most of post-bog meadows occurring in lowland bogs, which contributes to the initiation of multidirectional degradation processes of peat soils, as evidenced by the research conducted after 33 years of drainage and management of Supraśl Dolna object [Kiryluk 2016]. The biggest problem in these habitats is the lack of subsurface irrigation, decapitalization and non-functioning of drainage-irrigation networks, as well as the poor technical condition of ditches, as emphasized by Brandyk et al. 2006 and Kiryluk 2016. Improper use of post-bog meadows causes their further drying and intensification of moorshing process, as well as a change in phytocoenoses towards their synatropisation [Kiryluk 2007, Tomaszewska and Kołodziejczyk 2010]. Degradation results in a significant reduction in peat thickness, particularly in dry habitats, or complete disappearance of shallow peat beds. The effects also include large changes in habitats and overgrowing vegetation [Podlaska 2010]. The studies on peatlands in northwestern Germany have shown that peat settlement has been occurring during 50 years at the rate of $17 \mathrm{~cm} \cdot$ year $^{-1}$ [Günther 2013]. Studies on Kuwasy peatland showed that the average rate of murshic endofibric histosols settling between 1958 and 1982 was $1.34 \mathrm{~cm} \cdot$ year $^{-1}$ [Okruszko 1991]. Settlement of peatlands and reducing their thickness is an irreversible process, which reduces the utility value of peatlands and their natural function undergoes unfavorable changes. At present, no research is carried out in Poland and no practical solutions are put in place to preserve the semi-natural peatlands with high retention capacities and to restore these ecosystems. Multifaceted research is widely practiced in the USA and Canada [Gorham and Rochefort 2003]. The main way of managing valley peat bogs in Poland remains their, mostly extensive, use as meadow (69.6\%) [Ilnicki 2002]. 


\section{CONCLUSIONS}

1. In the deep peat-fibrous soil profile, the amplitude of groundwater level fluctuations was lower $(30-98 \mathrm{~cm})$ than in the moderately deep soil profile in dry habitat. Large changes in groundwater levels in dry habitats stimulated the degradation of peat-fiber soils.

2. In the period 1982-2015, the thickness of the moorsh layer in a humid habitat of peat-fibrous deep soil,increased by $3 \mathrm{~cm}$, while under dry conditions on moderately deep peat-moorsh soil, the moorsh level increased by $7 \mathrm{~cm}$.

3. The increase in bulk density as a result of moorshing process and settlement of peatlands affected the decrease in the overall porosity of examined soils.

4. As a result of mineralization and moorshing of the upper level of organic soils in the diagnostic level Oi (peat level) in dry and wet habitat, the overall porosity decreased. In dry habitat, porosity decreased by $1.5 \%$ vol., and under the conditions of optimum moisture content, only by $0.6 \%$ vol., while in dry habitat - only by $0.6 \%$ vol. Reduction in porosity also caused changes in soil retention capacity.

5. The highest full water capacity occurred in deep peat-fiber soil (profile No. 1) in the Oi peat diagnostic level and amounted to $89.4 \%$ vol. The water quality in this diagnostic level has slightly decreased over a 33-year period. Clear reduction in full water capacity was observed in moorsh level M1, both in wet and dry habitats.

\section{REFERENCES}

1. Brandyk T., Gnatowski T., Oleszczuk R., Szatyłowicz J., Szejba D., 2007. Progress in the study of the physical properties of peat-muck soils, [in:] Biernacka E. (ed.), Peat bogs and marshes. Wyd. SGGW,Warszawa, 91-112. (in Polish)

2. Brandyk T., Oleszczuk R., Szatyłowicz J.2006 Comparison of different ways of determining the water reserves in peat-muck soils used as meadows. Acta Agrophysica, 2006, 8(1), 11-21. (in Polish)

3. Cieśliński Z.1997. Characteristics of melioration treatments applied on hydrogenic soils [in:] Agromeliorations in shaping the agricultural environment. Edit. AR. Poznań, 236-258. (in Polish)

4. Gorham E.and Rochefort L.2003. Peatland restoration: A brief assessment with special reference to
Sphagnum bogs. () 2003 Kluwer Academic Publishers. Wetlands Ecology and Management, 11, 109-119.

5. GüntherJ.2013. Das Moor-und Fehnmuseum Elisabethfehn im Landkrteis Cloppenburg nach seiner Umgestaltung und Neuausrichtung. Telma 43, 199-154.

6. Ilnicki P.2002. Peat and peatland. Edit. AR Poznan, pp. 606. (in Polish)

7. Ilnicki P. Szajdak L.W, 2016. Peat bog fading, Edit. Poznańskie Towarzystwo Przyjaciół Nauk, pp. 312. (in Polish)

8. Joosten, H. 2000. Peatland conservation in central and southern Europe. In: Rochefort, L. and Daigle, J.Y. (eds.), Sustaining our peatlands. Proc. 11th Int. Peat Congress, Quebec City, Canada, August 6-12, 2000. Vol. 2, 1044-1049.

9. ISSUS Working Group WRB.2014. World Reference Base for Soil Resources. 2014. International soil classification system for naming soils and creating legends for soils map.World Solis Resources Reports, 106, FAO Rome, 181.

10. Kiryluk A.2007.Changes in post-bog habitats and phytocoenoses in the Supraśl river valley. Academic Theses and Monographs No. 20. IMUZ Falenty, pp.146. (in Polish)

11. Kiryluk A.2016. Assessment of technical condition and environmental functions of drainage facilities at Supraśl Dolna object. Inżynieria Ekologiczna 46, 38-46. (in Polish)

12. Okruszko H.1991. Results of many years of experience on the impact of use on peat soils. Wiad. Inst. Melior. Użyt. Ziel. 16(3), 87-107. (in Polish)

13. Pawluczuk J., Gotkiewicz J., 2003. Evaluation of the mineralization process in soils of selected peat ecosystems of North-Eastern Poland in an aspect of soil resources protection. Acta Agrophys. 1(4), 721-728. (in Polish)

14. Podlaska M.2010. Natural values of unused postbog meadows of Lower Silesia. Inżynieria Ekologiczna, 29, 130-140. (in Polish)

15. Renger M., Wessolek G., Schwärzel K., Sauerbrey R.,Siewert C.2002. Aspect of peat conservation and water management. J. Plant Nutr.Soil Sci. 165, 487-493.

16. Systematics of Polish Soils. 2011. Soil Science Annual (Roczniki Gleboznawcze) 62, 3, 5-142. (in Polish)

17. Sapek A., Sapek B., 1997. Methods of chemical analysis of organic soils. Mater. Instr.115. Falenty: Wydaw. IMUZ pp. 80. (in Polish)

18. Tomaszewska K., Kołodziejczyk K., 2010. Floristic diversity and natural values of unused post-bog meadows of Szczecin vicinity. Zeszyty Naukowe UP Wrocław, Rolnictwo, XCVII, 578, 43-58. (in Polish) 